\title{
Brain-Derived Neurotrophic Factor Val/Met Polymorphism and Bipolar Disorder
}

\author{
Association of the Met Allele with Suicidal Behavior of Bipolar Patients
}

\author{
Byungsu Kim Chang Yoon Kim Jin Pyo Hong Seong Yoon Kim Chul Lee \\ Yeon Ho Joo
}

Department of Psychiatry, Asan Medical Center, University of Ulsan College of Medicine, Seoul, Korea

\section{Key Words}

Bipolar disorder - Brain-derived neurotrophic factor •

Suicide

\begin{abstract}
Background/Aims: The substitution of valine by methionine in the brain-derived neurotrophic factor (BDNF Val/Met) gene alters the intracellular trafficking and regulated secretion of BDNF. This study tested whether the BDNF Val/Met polymorphism is associated with bipolar disorder in Korean subjects, and whether clinical features vary according to genotype. Methods: The allelic and genotypic distributions of BDNF Val/Met were determined in a population of $169 \mathrm{bi}-$ polar patients and 251 normal controls. Between-genotype comparisons of clinical features were performed without a priori knowledge of the genotype of individual patients. $R \boldsymbol{e}$ sults: Allelic distributions did not differ significantly between bipolar patients and controls $\left(\chi^{2}=0.400, p=0.821\right)$. However, the rate of suicide attempts among the $\mathrm{Val} / \mathrm{Val}$ (11.3\%), Val/Met (28.8\%) and Met/Met (38.9\%) genotype groups were significantly different $\left(\chi^{2}=9.879, \mathrm{p}=0.007\right)$. Relative to patients with the Val/Val genotype, those with the Met/Met genotype had a 4.9-fold higher risk of suicide attempts (95\% Cl, 1.7-14.7). Conclusions: These findings suggest that BDNF Val/Met is related to the suicidal behavior of bipolar patients, and may have clinical relevance as a biological indicator of bipolar patients at risk of suicide.
\end{abstract}

Copyright $\odot 2008$ S. Karger AG, Basel

\section{Introduction}

Neurotrophins provide necessary trophic support that leads to increased neuronal cell survival. Brain-derived neurotrophic factor (BDNF), a member of the neurotrophin family, is critical for the survival, differentiation and growth of neuronal cells [1-3]. In the adult central nervous system, BDNF is responsible not only for synaptic plasticity and dendritic growth, but also for long-term memory formation $[4,5]$. Thus, BDNF is involved in forming synapses and maintaining connections throughout the life cycle of neuronal cells. In addition, BDNF itself has direct antidepressant properties in animal models of depression, and protects neuronal cells against stress-induced neural damage [6]. These results have suggested that BDNF is a susceptibility gene for various psychiatric disorders, including schizophrenia [7], eating disorders $[8,9]$, obsessive compulsive disorder [10] and bipolar disorder [11, 12].

Of the known polymorphisms in the BDNF gene, a single nucleotide polymorphism (SNP) at nucleotide 196 (G/A), which leads to the substitution of methionine for valine in the region encoding the prodomain (Val/Met, rs6265), has been shown to have functional consequences [13-16]. The Met allele has been associated with impairments in intracellular trafficking and activity-dependent secretion of BDNF in neurons and neurosecretory cells [13-16]. These impairments are consistent with the functional deficits associated with the BDNF Met allele in

\section{KARGER}

Fax +41613061234 E-Mail karger@karger.ch www.karger.com

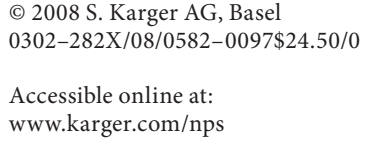


human subjects, including poorer episodic memory [15], reduced hippocampal volume $[17,18]$ and reduced gray matter volume in the dorsolateral prefrontal cortex [18].

Although the Val/Met polymorphism has functional effects, the biological relevance of this polymorphism to bipolar disorder remains unclear. Two family-based studies found that BDNF Val/Met has a significant association with bipolar disorder, with the Val allele showing increased susceptibility [11, 12]. Additional attempts to replicate these findings, however, have yielded inconsistent results [19]. In particular, a negative association between BDNF Val/Met and bipolar disorder was observed in Japanese and Han Chinese subjects [20-22], whereas a positive association was observed in predominantly Caucasian populations $[11,12,23]$. Moreover, the allele frequencies of BDNF Val/Met have been found to differ significantly between individuals of European and Asian descent [24], suggesting that the association of BDNF $\mathrm{Val} / \mathrm{Met}$ with bipolar disorder should be assessed separately in different ethnic populations. To our knowledge, there have been no studies to date on the association of BDNF Val/Met with bipolar disorder in Koreans.

Instead of exerting a global influence in bipolar disorder, BDNF Val/Met may have a role in specific subgroups of bipolar patients or those with particular psychiatric symptom(s). For example, BDNF Val/Met was shown to be associated with childhood-onset affective disorder $[25,26]$ and rapid cycling $[27,28]$. Moreover, this polymorphism may contribute to the development of particular clinical subphenotypes rather than bipolar disorder per se. For example, bipolar patients with the Met allele performed more poorly on the Wisconsin Card Sorting Test than bipolar patients homozygous for the Val allele [29-31], indicating that this polymorphism may be associated with different clinical variables commonly present in bipolar disorder. Thus, it is of interest to determine the association of BDNF Val/Met with clinical features that are frequently present in bipolar patients.

This study was designed to test whether the BDNF $\mathrm{Val} / \mathrm{Met}$ polymorphism is associated with bipolar disorder in Korean subjects, and whether clinical features vary according to genotype.

\section{Methods}

\section{Subjects}

This study involved 169 Korean patients (75 males, 94 females; mean age $37.5 \pm 12.3$ years) diagnosed with type I and II bipolar disorders, as defined by DSM-IV criteria. All subjects were enrolled in the psychiatric department at a university tertiary hos- pital (Asan Medical Center, University of Ulsan College of Medicine, Seoul, Korea). Diagnosis was confirmed using the Structured Clinical Interview for DSM-IV, and collateral information was collected from unstructured interviews of the subject and the family members, and from medical records. The control group consisted of 251 normal healthy individuals (108 males, $143 \mathrm{fe}$ males; mean age $35.3 \pm 11.2$ years) with no history of psychiatric disorders, including suicide attempts. Written informed consent was obtained from all participants after explaining the aims and procedures of the study. This study was approved by the Ethics Committee of the Asan Medical Center.

\section{Assessment of Clinical Features}

Clinical information on bipolar patients was collected from direct interviews with individual patients and family members, and from medical records. Clinical features evaluated included: age of onset, psychotic symptoms, mixed episodes, rapid cycling, alcohol problems (abuse or dependence), any psychiatric family history within second-degree relatives, family history of bipolar disorder within second-degree relatives, history of suicide attempts and lethality of suicide attempts. The latter was assessed using a Lethality of Suicide Attempt Rating Scale [32]. If subjects had a history of more than 1 suicide attempt, the most lethal attempt was evaluated. All assessments were performed without a priori knowledge of the genotypic status of individual patients.

\section{Genotyping of BDNF $\mathrm{Val} / \mathrm{Met}$}

Venous blood $(10 \mathrm{ml})$ was collected from each patient and normal controls, and genomic DNA was isolated from peripheral blood leukocytes using standard proteinase-K-RNase digestion procedures followed by phenol-chloroform extraction. BDNF Val/Met polymorphisms (rs6265) were identified by genotyping using a single-base primer-extension assay (ABI Prism SNaPshot Multiplex Kit; ABI, Foster City, Calif., USA) according to the manufacturer's recommendations. Genomic DNA flanking the SNP (rs6265) was amplified by PCR using the primers 5'-TGATGACCATCCTTTTCCTT-3' (forward) and 5'-CACTGGGAGTTCCAATGC-3' (reverse). Each PCR reaction utilized $10 \mathrm{ng}$ genomic DNA, $0.5 \mathrm{pM}$ of each oligonucleotide primer, $1 \mu \mathrm{l} 10 \times \mathrm{PCR}$ gold buffer, $250 \mu \mathrm{M}$ dNTP, $3 \mathrm{mM} \mathrm{MgCl}_{2}$ and 0.25 unit i-StarTaq DNA polymerase (iNtRON Biotechnology, Sungnam, KyungkiDo, Korea) in a total reaction volume of $10 \mu l$. The amplification protocol consisted of 1 cycle of denaturation at $95^{\circ} \mathrm{C}$ for $10 \mathrm{~min}$, 30 cycles of denaturation at $95^{\circ} \mathrm{C}$ for $30 \mathrm{~s}$, annealing at $55^{\circ} \mathrm{C}$ for $1 \mathrm{~min}$ and extension at $72^{\circ} \mathrm{C}$ for $1 \mathrm{~min}$, followed by a final extension at $72^{\circ} \mathrm{C}$ for $7 \mathrm{~min}$. The PCR products were treated with 1 unit of shrimp alkaline phosphatase (Roche, Basel, Switzerland) and 1 unit of exonuclease I (USB Corporation, Cleveland, Ohio, USA) for $60 \mathrm{~min}$ at $37^{\circ} \mathrm{C}$ followed by $15 \mathrm{~min}$ at $72^{\circ} \mathrm{C}$ to purify the amplified products. A $1-\mu l$ aliquot of each purified amplification product was added to a SNaPshot Multiplex Ready Reaction mixture containing $0.15 \mathrm{pM}$ genotyping primer for the primer extension reaction, which consisted of 25 cycles at $96^{\circ} \mathrm{C}$ for $10 \mathrm{~s}, 50^{\circ} \mathrm{C}$ for $5 \mathrm{~s}$ and $60^{\circ} \mathrm{C}$ for $30 \mathrm{~s}$. These reaction products were treated with 1 unit of shrimp alkaline phosphatase for $1 \mathrm{~h}$ at $37^{\circ} \mathrm{C}$, followed by $15 \mathrm{~min}$ at $72^{\circ} \mathrm{C}$ to remove excess fluorescent dye terminators. A $1-\mu \mathrm{l}$ aliquot of each sample was added to $9 \mu \mathrm{l}$ of $\mathrm{Hi}-\mathrm{Di}$ formamide (ABI), and incubated at $95^{\circ} \mathrm{C}$ for $5 \mathrm{~min}$, followed by $5 \mathrm{~min}$ on ice. The reaction products were analyzed by electrophoresis using an ABI Prism 3730xl DNA analyzer, and results were interpreted using GeneScan analysis software (ABI). 
Table 1. BDNF Val/Met polymorphism: allele and genotype distributions between bipolar patients and normal controls

\begin{tabular}{llrll}
\hline & $\begin{array}{l}\text { Case } \\
(\mathrm{n}=169)\end{array}$ & $\begin{array}{l}\text { Control } \\
(\mathrm{n}=251)\end{array}$ & $\chi^{2}$ & $\mathrm{p}$ \\
\hline Val & $186(55.0)$ & $268(53.4)$ & & \\
Met & $152(45.0)$ & $234(46.6)$ & 0.400 & 0.821 \\
\hline Val/Val & $53(31.4)$ & $77(30.7)$ & & \\
Val/Met & $80(47.3)$ & $114(45.4)$ & & \\
Met/Met & $36(21.3)$ & $60(23.9)$ & 0.220 & 0.640 \\
\hline
\end{tabular}

Figures in parentheses are percentages.

Statistical Analysis

The genotype frequency was assessed for conformance to a Hardy-Weinberg equilibrium using a $\chi^{2}$ test. Statistical differences in genotype and allele frequencies between bipolar patients and controls were evaluated by a $\chi^{2}$ test or Fisher's exact test. Comparisons among BDNF Val/Met genotype groups were performed using Fisher's exact test for categorical data and ANOVA for continuous variables. Linear regression analysis was adapted to test the linearity between the number of Met alleles of individual patients and suicide lethality scores. All statistical analyses were performed with SPSS version 12.0. Statistical significance was defined as $\mathrm{p}<0.05$.

\section{Results}

\section{BDNF Val/Met Allele and Genotype Frequencies in}

Bipolar Patients and Normal Controls

The BDNF Val/Met allele frequency and genotype distribution were compatible with a Hardy-Weinberg equilibrium, both in bipolar subjects $\left(\chi^{2}=0.321, \mathrm{p}=0.852\right)$ and in normal controls $\left(\chi^{2}=1.919, \mathrm{p}=0.383\right)$. There were no statistically significant differences in allele $\left(\chi^{2}=0.400\right.$, $\mathrm{p}=0.821)$ or genotype $\left(\chi^{2}=0.220, \mathrm{p}=0.640\right)$ frequency between bipolar patients and normal controls (table 1).

\section{Comparisons of Clinical Features according to BDNF $\mathrm{Val} / \mathrm{Met}$ Genotypes}

Val/Val, Val/Met and Met/Met bipolar patient groups were not significantly different with respect to age, sex, proportions of bipolar type I and II patients, or the duration of the disorder (table 2). The only clinical features that were significantly different among the 3 genotype groups were suicide attempt and suicide lethality (table 2). Of the 169 bipolar patients, 43 (25.4\%) had a history of previous suicide attempt(s). The rate of suicide attempts among the Val/Val (11.3\%), Val/Met (28.8\%)
Bipolar patients with history of suicide attempt/s (\%)

Bipolar patients without history of suicide attempt/s (\%)

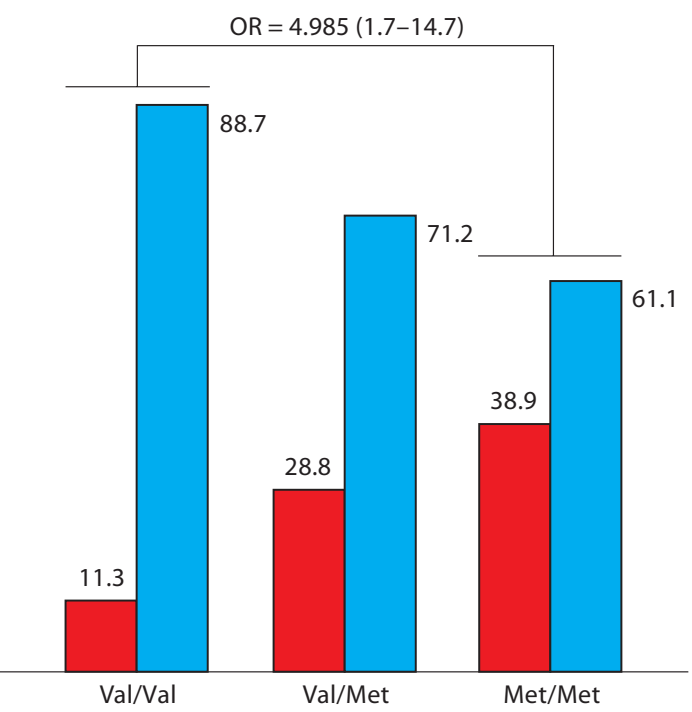

Fig. 1. Comparisons of frequency of suicide attempters according to genotype of BDNF Val/Met.

and Met/Met (38.9\%) genotype groups were significantly different $\left(\chi^{2}=9.879, \mathrm{p}=0.007\right)$. Relative to patients with the Val/Val genotype, those with the Met/Met genotype had a 4.9 -fold higher risk of suicide attempts (95\% CI, 1.7-14.7; fig. 1). A comparison of the allelic distribution of the Val/Met polymorphism in normal controls and bipolar subjects with a history of suicide attempt(s) showed a significantly higher frequency of the Met allele in suicidal bipolar subjects than in normal controls (59.3 vs. $46.6 \% ; \chi^{2}=4.733, p=0.035$ ).

\section{Discussion}

Although we did not observe a significant association between bipolar disorder and the BDNF Val/Met polymorphism, we found a significant association between this polymorphism and the suicidal behavior of bipolar patients; to our knowledge, this study is the first to report such an association. In agreement with our findings, a recent meta-analysis of 11 case-control studies [19], an analysis of 3,062 Caucasian subjects in the UK [27] and additional studies in Asian subjects [20-22] showed no 
Table 2. Comparisons of clinical features according to BDNF Val/Met genotype groups

\begin{tabular}{|c|c|c|c|c|c|}
\hline & $\begin{array}{l}\mathrm{Val} / \mathrm{Val} \\
(\mathrm{n}=53)\end{array}$ & $\begin{array}{l}\text { Val/Met } \\
(\mathrm{n}=80)\end{array}$ & $\begin{array}{l}\text { Met/Met } \\
(\mathrm{n}=36)\end{array}$ & Statistics & $\mathrm{p}$ values \\
\hline Age, years & $36.5 \pm 11.6$ & $37.9 \pm 12.8$ & $37.1 \pm 12.3$ & $\mathrm{~F}=0.199$ & $0.820^{\mathrm{a}}$ \\
\hline Female sex & $27(50.9)$ & $48(60.0)$ & $19(52.8)$ & $\chi^{2}=1.232$ & $0.576^{\mathrm{b}}$ \\
\hline Bipolar type I:bipolar type II & $41: 12$ & $60: 20$ & $26: 10$ & $\chi^{2}=0.353$ & $0.845^{\mathrm{b}}$ \\
\hline Duration of illness, years & $9.4 \pm 8.7$ & $8.9 \pm 8.3$ & $10.8 \pm 8.9$ & $\hat{\mathrm{F}}=0.562$ & $0.571^{\mathrm{a}}$ \\
\hline Age of onset, years & $27.6 \pm 8.8$ & $28.9 \pm 11.6$ & $25.7 \pm 8.4$ & $\mathrm{~F}=1.211$ & $0.301^{\mathrm{a}}$ \\
\hline Psychotic symptoms & $21(39.6)$ & $33(41.3)$ & $17(47.2)$ & $\chi^{2}=0.568$ & $0.790^{\mathrm{b}}$ \\
\hline Mixed episode & $14(26.4)$ & $22(27.5)$ & $12(33.3)$ & $\hat{\chi}^{2}=0.611$ & $0.736^{\mathrm{b}}$ \\
\hline Rapid cycling & $4(7.5)$ & $6(7.5)$ & $5(13.9)$ & $\chi^{2}=1.470$ & $0.526^{\mathrm{b}}$ \\
\hline Alcohol problems & $6(11.3)$ & $11(13.8)$ & $4(11.1)$ & $\chi^{2}=0.231$ & $0.911^{\mathrm{b}}$ \\
\hline Any psychiatric family history & $21(39.6)$ & $19(23.8)$ & $9(25.0)$ & $\chi^{2}=4.102$ & $0.126^{\mathrm{b}}$ \\
\hline Family history of bipolar disorder & $6(11.3)$ & $7(8.8)$ & $2(5.6)$ & $\chi^{2}=0.819$ & $0.685^{\mathrm{b}}$ \\
\hline Suicide attempt & $6(11.3)$ & $23(28.8)$ & $14(38.9)$ & $\chi^{2}=9.879$ & $0.007^{\mathrm{b}}$ \\
\hline Lethality of suicide attempt $(0-10)$, score & $2.83 \pm 1.4$ & $4.00 \pm 2.1$ & $4.89 \pm 2.3$ & $\hat{\mathrm{F}}=4.257$ & $0.045^{\mathrm{c}}$ \\
\hline
\end{tabular}

Where indicated, results are presented as means \pm SD. Figures in parentheses are percentages.

${ }^{a}$ ANOVA. ${ }^{b}$ Fisher's exact test. ${ }^{c}$ Linear regression for testing trend.

significant association between bipolar disorder and BDNF Val/Met. However, this polymorphism has been shown to be associated with particular subgroups of bipolar patients, including childhood-onset $[25,26]$ and rapid cycling $[27,28]$. In addition to its association with specific phenotypes, bipolar patients with the Met allele showed poorer performance on the Wisconsin Card Sorting Test than bipolar patients homozygous for the Val allele [29-31]. These results indicate that the BDNF Val/ Met polymorphism is related to particular clinical features commonly appearing in bipolar disorder, rather than to bipolar disorder per se. Thus, it may be premature to conclude that this polymorphism plays no role in the etiopathogenesis of bipolar disorder or the development of its clinical manifestations.

An analysis of the associations between the Val/Met polymorphism and specific clinical features that usually accompany bipolar disorder showed that suicide attempt was significantly associated with the Met allele. This allele also exerted a dosage effect on the lethality of suicidal behavior: suicidal behavior became more lethal as the number of Met alleles increased. These results suggest that clinical feature(s) may vary according to the genotypic status of BDNF Val/Met, even among patients who fall within the same bipolar disorder diagnostic boundary.

In contrast to our finding of an association between BDNF Val/Met and suicidal behavior in patients with bi- polar disorder, a previous study has reported that this genotype did not have a significant effect on suicidal history in patients with mood disorder [20]. Bipolar patients, however, are at higher risk of suicide and their suicidal behavior has a higher lethality [33] than that of patients with other psychiatric disorders [34]. Suicidal patients may represent a distinct subgroup of bipolar patients [35], possibly with a different genetic background [36]. Patients with bipolar disorder have a lifetime suicide risk of $19 \%$, and $25-50 \%$ of these patients attempt suicide at least once during the course of their illness [34,37]. Of our bipolar patients, $25 \%$ reported a history of suicide attempt(s), which is within the reported range.

BDNF may play a role in suicidal behavior. For example, BDNF levels in the hippocampus and prefrontal cortex were significantly lower in suicide victims who were drug-free compared with nonsuicide controls, regardless of diagnosis [38, 39]. In addition, depressive patients who attempted suicide had lower plasma concentrations of BDNF than depressive patients without a history of suicide attempts [40]. Furthermore, lithium, which is used to reduce suicide risk, increases BDNF levels [41, 42]. Although there is little direct evidence to indicate how the Met allele might lead to suicidal behavior, previous results suggest several hypotheses. For example, bipolar patients with the Met allele may have an impairment in the regulated secretion of $\mathrm{BDNF}[14,15]$ that alters BDNF levels, as observed in suicidal patients. In addition, the 
Met allele has been associated with genetic predispositions to anxiety and depressive disorders, as evidenced by the increase in antidepressant-resistant anxiety-related behaviors in BDNF Met/Met mice [16]. These results suggest that the suicidal behavior of bipolar patients may be due to an increased vulnerability to anxiety associated with the Met allele, since comorbid anxiety is a known risk factor for suicide in bipolar disorder [43].

The serotonergic system is also related to suicidal behavior. Suicidal behavior runs within families independently of the transmission of psychiatric illness itself and is linked to serotonergic dysfunction [44, 45]. BDNF modulates the activity of many neurotransmitter systems, including the serotonergic system $[46,47]$. A deficit in BDNF is also associated with behavioral alterations, including the development of aggressiveness and hyperphagia, which are associated with a decrease in serotonin concentrations [48-50]. These findings suggest that the contribution of BDNF to suicidal behavior implied by our results may be mediated by the serotonergic system; however, additional experimental and clinical studies will be required to confirm this speculation. One subject that warrants further investigation is the interaction of BDNF with other genes and genetic variants associated with susceptibility to suicidal behavior, such as 5-HTTLPR (serotonin transporter gene-linked promoter region). It is likely that multiple genes are involved, each of which may make only a minor contribution to mood disorder and suicidal behavior.

Ethnic differences have been observed in the genotype and allele frequencies of BDNF Val/Met. For example, our control group had a higher frequency of the Met allele (46.6\%) than that in Western populations (19.0\% in Caucasian citizens of the UK) [27]. However, the Met allele frequency we observed is similar to that in other Asian populations [20-22]; in Japanese subjects, the Met allele frequencies were between 41 and 48\% [21, 22]. Significant differences in BDNF Val/Met genotype frequency have been observed in populations in Japan, the USA and Italy [24]. These differences may influence the results of case-control studies of genetic associations, and lead to inconsistencies between reports based on different populations.

Our study had several limitations. First, our failure to observe a significant association between the BDNF Val/ Met and overall bipolar patients may be due to an insufficient number of subjects. In addition, the association between BDNF Val/Met and suicidal behavior of bipolar patients could possibly reflect a type I error due to multiple comparison of clinical variables; however, our sta- tistical association $(p=0.007)$ remained significant after correction $(p=0.049)$. Second, the retrospective assessment of clinical features, including history of suicide attempt(s), is subject to recall bias. However, we tried to minimize the impact of bias by supplementing patient recall with collateral information from all available medical records and from interviews with close relatives. Third, there might have been confounding variables not tested in this study that contributed to the association between BDNF Val/Met and the suicidal behavior of bipolar patients. For example, depressive and mixed states have been associated with a high risk of suicide in bipolar patients [35]. Since most suicide attempts by bipolar patients occur during depressive or mixed states [51], bipolar patients carrying the Met allele may be more vulnerable to depressive symptoms as well as suicidal behavior. This is supported by evidence of an association between the Met allele and geriatric depression [52], post-stroke depression [53] and the risk of depression, the latter through interactions with the serotonin transporter gene [54-56]. Although the Val allele has been associated with susceptibility to bipolar disorder [11, 12], this speculative relationship should be validated by a systematic assessment of the severity of depressive symptoms in bipolar disorder patients. The fourth limitation of our study was that we did not evaluate other SNP of the BDNF gene that might be involved in BDNF production and function. Therefore, we cannot exclude associations between other polymorphism(s) in regulatory or coding regions of BDNF and bipolar disorder. Furthermore, the association between BDNF Val/Met and the suicidal behavior of bipolar patients may have resulted from another unknown functional polymorphism(s) in linkage disequilibrium with BDNF Val/Met.

In conclusion, our findings suggest that the BDNF gene may be associated with susceptibility to suicidal behavior of bipolar patients. Due to genetic and phenotypic heterogeneities in psychiatric disorders, including bipolar disorder, patients satisfying the same formal bipolar disorder diagnostic criteria may present with distinct clinical features that have different genetic bases. Our results may have clinical implications in that they suggest that BDNF Val/Met may be a biological indicator for bipolar patients at risk of suicide. Prospective studies on a larger patient population are required to validate this association. 


\section{References}

1 Lewin GR, Barde YA: Physiology of the neurotrophins. Ann Rev Neurosci 1996;19:289317.

-2 Maisonpierre PC, Belluscio L, Friedman B, Alderson RF, Wiegand SJ, Furth ME, Lindsay RM, Yancopoulos GD: Nt-3, BDNF, and NGF in the developing rat nervous system: parallel as well as reciprocal patterns of expression. Neuron 1990;5:501-509.

$\checkmark 3$ Huang EJ, Reichardt LF: Neurotrophins: roles in neuronal development and function. Ann Rev Neurosci 2001;24:677-736.

$\checkmark 4$ Thoenen H: Neurotrophins and neuronal plasticity. Science 1995;270:593-598.

$\checkmark 5$ Figurov A, Pozzo-Miller LD, Olafsson P, Wang T, Lu B: Regulation of synaptic responses to high-frequency stimulation and LTP by neurotrophins in the hippocampus. Nature 1996;381:706-709.

6 Hashimoto K, Shimizu E, Iyo M: Critical role of brain-derived neurotrophic factor in mood disorders. Brain Res Brain Res Rev 2004;45:104-114.

$\checkmark 7$ Neves-Pereira M, Cheung JK, Pasdar A, Zhang F, Breen G, Yates P, Sinclair M, Crombie C, Walker N, St Clair DM: BDNF gene is a risk factor for schizophrenia in a Scottish population. Mol Psychiatry 2005;10:208212.

$\checkmark 8$ Ribases M, Gratacos M, Armengol L, de Cid R, Badia A, Jimenez L, Solano R, Vallejo J, Fernandez F, Estivill X: Met66 in the brainderived neurotrophic factor (BDNF) precursor is associated with anorexia nervosa restrictive type. Mol Psychiatry 2003;8:745751.

-9 Ribases M, Gratacos M, Fernandez-Aranda F, Bellodi L, Boni C, Anderluh M, Cavallini MC, Cellini E, Di Bella D, Erzegovesi S, Foulon C, Gabrovsek M, Gorwood P, Hebebrand J, Hinney A, Holliday J, Hu X, Karwautz A, Kipman A, Komel R, Nacmias B, Remschmidt H, Ricca V, Sorbi S, Wagner G, Treasure J, Collier DA, Estivill X: Association of BDNF with anorexia, bulimia and age of onset of weight loss in six European populations. Hum Mol Genet 2004;13:12051212.

10 Hall D, Dhilla A, Charalambous A, Gogos JA, Karayiorgou M: Sequence variants of the brain-derived neurotrophic factor (BDNF) gene are strongly associated with obsessivecompulsive disorder. Am J Hum Genet 2003; 73:370-376.

-11 Neves-Pereira M, Mundo E, Muglia P, King N, Macciardi F, Kennedy JL: The brain-derived neurotrophic factor gene confers susceptibility to bipolar disorder: evidence from a family-based association study. Am J Hum Genet 2002;71:651-655.
12 Sklar P, Gabriel SB, McInnis MG, Bennett P, Lim YM, Tsan G, Schaffner S, Kirov G, Jones I, Owen M, Craddock N, DePaulo JR, Lander ES: Family-based association study of 76 candidate genes in bipolar disorder: BDNF is a potential risk locus. Brain-derived neutrophic factor. Mol Psychiatry 2002;7:579-593.

13 Chen ZY, Ieraci A, Teng H, Dall H, Meng CX, Herrera DG, Nykjaer A, Hempstead BL, Lee FS: Sortilin controls intracellular sorting of brain-derived neurotrophic factor to the regulated secretory pathway. J Neurosci 2005; 25:6156-6166

14 Chen ZY, Patel PD, Sant G, Meng CX, Teng KK, Hempstead BL, Lee FS: Variant brainderived neurotrophic factor (BDNF) (Met66) alters the intracellular trafficking and activity-dependent secretion of wild-type BDNF in neurosecretory cells and cortical neurons. J Neurosci 2004;24:4401-4411.

15 Egan MF, Kojima M, Callicott JH, Goldberg TE, Kolachana BS, Bertolino A, Zaitsev E, Gold B, Goldman D, Dean M, Lu B, Weinberger DR: The BDNF val66met polymorphism affects activity-dependent secretion of BDNF and human memory and hippocampal function. Cell 2003;112:257-269.

16 Chen ZY, Jing D, Bath KG, Ieraci A, Khan T, Siao CJ, Herrera DG, Toth M, Yang C, McEwen BS, Hempstead BL, Lee FS: Genetic variant BDNF (Val66Met) polymorphism alters anxiety-related behavior. Science 2006;314:140-143.

$>17$ Bueller JA, Aftab M, Sen S, Gomez-Hassan D, Burmeister M, Zubieta JK: BDNF Val$66 \mathrm{Met}$ allele is associated with reduced hippocampal volume in healthy subjects. Biol Psychiatry 2006;59:812-815.

18 Pezawas L, Verchinski BA, Mattay VS, Callicott JH, Kolachana BS, Straub RE, Egan MF, Meyer-Lindenberg A, Weinberger DR: The brain-derived neurotrophic factor val66met polymorphism and variation in human cortical morphology. J Neurosci 2004;24:10099_ 10102.

19 Kanazawa T, Glatt SJ, Kia-Keating B, Yoneda $\mathrm{H}$, Tsuang MT: Meta-analysis reveals no association of the Val66Met polymorphism of brain-derived neurotrophic factor with either schizophrenia or bipolar disorder. Psychiatr Genet 2007;17:165-170.

20 Hong CJ, Huo SJ, Yen FC, Tung CL, Pan GM, Tsai SJ: Association study of a brain-derived neurotrophic-factor genetic polymorphism and mood disorders, age of onset and suicidal behavior. Neuropsychobiology 2003;48: 186-189.

21 Kunugi H, Iijima Y, Tatsumi M, Yoshida M, Hashimoto R, Kato T, Sakamoto K, Fukunaga T, Inada T, Suzuki T, Iwata N, Ozaki N, Yamada K, Yoshikawa T: No association between the Val66Met polymorphism of the brain-derived neurotrophic factor gene and bipolar disorder in a Japanese population: a multicenter study. Biol Psychiatry 2004;56: 376-378.
22 Nakata K, Ujike H, Sakai A, Uchida N, Nomura A, Imamura T, Katsu T, Tanaka Y, Hamamura T, Kuroda S: Association study of the brain-derived neurotrophic factor (BDNF) gene with bipolar disorder. Neurosci Lett 2003;337:17-20.

23 Lohoff FW, Sander T, Ferraro TN, Dahl JP, Gallinat J, Berrettini WH: Confirmation of association between the Val66Met polymorphism in the brain-derived neurotrophic factor (BDNF) gene and bipolar I disorder. Am J Med Genet B Neuropsychiatr Genet 2005;139:51-53.

24 Shimizu E, Hashimoto K, Iyo M: Ethnic difference of the BDNF 196G/A (val66met) polymorphism frequencies: the possibility to explain ethnic mental traits. Am J Med Genet B Neuropsychiatr Genet 2004;126:122123.

25 Strauss J, Barr CL, George CJ, Devlin B, Vetro A, Kiss E, Baji I, King N, Shaikh S, Lanktree M, Kovacs M, Kennedy JL: Brain-derived neurotrophic factor variants are associated with childhood-onset mood disorder: confirmation in a Hungarian sample. Mol Psychiatry 2005;10:861-867.

26 Geller B, Badner JA, Tillman R, Christian SL, Bolhofner K, Cook EH Jr: Linkage disequilibrium of the brain-derived neurotrophic factor Val66Met polymorphism in children with a prepubertal and early adolescent bipolar disorder phenotype. Am J Psychiatry 2004;161:1698-1700.

27 Green EK, Raybould R, Macgregor S, Hyde $\mathrm{S}$, Young AH, O’Donovan MC, Owen MJ, Kirov G, Jones L, Jones I, Craddock N: Genetic variation of brain-derived neurotrophic factor (BDNF) in bipolar disorder: casecontrol study of over 3,000 individuals from the UK. Br J Psychiatry 2006;188:21-25.

28 Muller DJ, de Luca V, Sicard T, King N, Strauss J, Kennedy JL: Brain-derived neurotrophic factor (BDNF) gene and rapid-cycling bipolar disorder: family-based association study. Br J Psychiatry 2006;189: 317-323.

29 Rybakowski JK, Borkowska A, Czerski PM, Skibinska M, Hauser J: Polymorphism of the brain-derived neurotrophic factor gene and performance on a cognitive prefrontal test in bipolar patients. Bipolar Disord 2003;5:468472 .

30 Rybakowski JK, Borkowska A, Skibinska M, Hauser J: Illness-specific association of val66met BDNF polymorphism with performance on Wisconsin Card Sorting Test in bipolar mood disorder. Mol Psychiatry 2006; 11:122-124.

31 Rybakowski JK, Borkowska A, Skibinska M, Szczepankiewicz A, Kapelski P, Leszczynska-Rodziewicz A, Czerski PM, Hauser J: Prefrontal cognition in schizophrenia and bipolar illness in relation to Val66Met polymorphism of the brain-derived neurotrophic factor gene. Psychiatry Clin Neurosci 2006;60:70-76. 
-32 Smith K, Conroy RW, Ehler BD: Lethality of suicide attempt rating scale. Suicide Life Threat Behav 1984;14:215-242.

>33 Baldessarini RJ, Pompili M, Tondo L: Suicide in bipolar disorder: risks and management. CNS Spectr 2006;11:465-471.

34 Chen YW, Dilsaver SC: Lifetime rates of suicide attempts among subjects with bipolar and unipolar disorders relative to subjects with other axis I disorders. Biol Psychiatry 1996;39:896-899.

35 Slama F, Bellivier F, Henry C, Rousseva A, Etain B, Rouillon F, Leboyer M: Bipolar patients with suicidal behavior: toward the identification of a clinical subgroup. J Clin Psychiatry 2004;65:1035-1039.

-36 Willour VL, Zandi PP, Badner JA, Steele J, Miao K, Lopez V, MacKinnon DF, Mondimore FM, Schweizer B, McInnis MG, Miller EB, Depaulo JR Jr, Gershon ES, McMahon FJ, Potash JB: Attempted suicide in bipolar disorder pedigrees: evidence for linkage to 2p12. Biol Psychiatry 2007;61:725-727.

37 Jamison KR: Suicide and bipolar disorder. J Clin Psychiatry 2000;61(suppl 9):47-51.

>38 Karege F, Vaudan G, Schwald M, Perroud N, La Harpe R: Neurotrophin levels in postmortem brains of suicide victims and the effects of antemortem diagnosis and psychotropic drugs. Brain Res Mol Brain Res 2005; 136:29-37.

-39 Dwivedi Y, Rizavi HS, Conley RR, Roberts RC, Tamminga CA, Pandey GN: Altered gene expression of brain-derived neurotrophic factor and receptor tyrosine kinase $\mathrm{B}$ in postmortem brain of suicide subjects. Arch Gen Psychiatry 2003;60:804-815.

$\checkmark 40$ Kim YK, Lee HP, Won SD, Park EY, Lee HY, Lee BH, Lee SW, Yoon D, Han C, Kim DJ, Choi SH: Low plasma BDNF is associated with suicidal behavior in major depression. Prog Neuropsychopharmacol Biol Psychiatry 2007;31:78-85.
41 Einat H, Yuan P, Gould TD, Li J, Du J, Zhang L, Manji HK, Chen G: The role of the extracellular signal-regulated kinase signaling pathway in mood modulation. J Neurosci 2003;23:7311-7316.

42 Fukumoto T, Morinobu S, Okamoto Y, Kagaya A, Yamawaki S: Chronic lithium treatment increases the expression of brain-derived neurotrophic factor in the rat brain. Psychopharmacology (Berl) 2001;158:100106.

43 Simon NM, Zalta AK, Otto MW, Ostacher MJ, Fischmann D, Chow CW, Thompson EH, Stevens JC, Demopulos CM, Nierenberg AA, Pollack MH: The association of comorbid anxiety disorders with suicide attempts and suicidal ideation in outpatients with bipolar disorder. J Psychiatr Res 2007;41:255264.

44 Bondy B, Buettner A, Zill P: Genetics of suicide. Mol Psychiatry 2006;11:336-351.

-45 Courtet P, Picot MC, Bellivier F, Torres S, Jollant F, Michelon C, Castelnau D, Astruc B, Buresi C, Malafosse A: Serotonin transporter gene may be involved in short-term risk of subsequent suicide attempts. Biol Psychiatry 2004;55:46-51.

46 Cotman CW, Berchtold NC: Exercise: a behavioral intervention to enhance brain health and plasticity. Trends Neurosci 2002; 25:295-301.

47 Mossner R, Daniel S, Albert D, Heils A, Okladnova O, Schmitt A, Lesch KP: Serotonin transporter function is modulated by brain-derived neurotrophic factor (BDNF) but not nerve growth factor (NGF). Neurochem Int 2000;36:197-202.

48 Lyons WE, Mamounas LA, Ricaurte GA Coppola V, Reid SW, Bora SH, Wihler C, Koliatsos VE, Tessarollo L: Brain-derived neurotrophic factor-deficient mice develop aggressiveness and hyperphagia in conjunction with brain serotonergic abnormalities. Proc Natl Acad Sci USA 1999;96:15239-15244.
49 Kernie SG, Liebl DJ, Parada LF: BDNF regulates eating behavior and locomotor activity in mice. EMBO J 2000;19:1290-1300.

50 Rios M, Fan G, Fekete C, Kelly J, Bates B, Kuehn R, Lechan RM, Jaenisch R: Conditional deletion of brain-derived neurotrophic factor in the postnatal brain leads to obesity and hyperactivity. Mol Endocrinol 2001; 15:1748-1757.

51 Tondo L, Baldessarini RJ, Hennen J, Floris G, Silvetti F, Tohen M: Lithium treatment and risk of suicidal behavior in bipolar disorder patients. J Clin Psychiatry 1998;59:405-414.

52 Hwang JP, Tsai SJ, Hong CJ, Yang CH, Lirng JF, Yang YM: The Val66Met polymorphism of the brain-derived neurotrophic-factor gene is associated with geriatric depression. Neurobiol Aging 2006;27:1834-1837.

$\checkmark 53$ Kim JM, Stewart R, Kim SW, Yang SJ, Shin IS, Kim YH, Yoon JS: BDNF genotype potentially modifying the association between incident stroke and depression. Neurobiol Aging 2008;29:789-792.

54 Anttila S, Huuhka K, Huuhka M, Rontu R, Hurme M, Leinonen E, Lehtimäki T: Interaction between 5-HT1A and BDNF genotypes increases the risk of treatment-resistant depression. J Neural Transm 2007;114: 1065-1068.

55 Kaufman J, Yang BZ, Douglas-Palumberi H, Grasso D, Lipschitz D, Houshyar S, Krystal $\mathrm{JH}$, Gelernter J: Brain-derived neurotrophic factor-5-HTTLPR gene interactions and environmental modifiers of depression in children. Biol Psychiatry 2006;59:673-680.

56 Kim JM, Stewart R, Kim SW, Yang SJ, Shin IS, Kim YH, Yoon JS: Interactions between life stressors and susceptibility genes (5-HTTLPR and BDNF) on depression in Korean elders. Biol Psychiatry 2007;62:423-428. 